\title{
Species composition of fungı causing diseases in agricultural plants in agrarian sector of Azerbaijan
}

\author{
P.Z. Muradov* \\ Azerbaijan National Academy of Sciences, Institute of Microbiology, Baku, Republic of \\ Azerbaijan \\ G.F.Shirinova \\ Azerbaijan National Academy of Sciences, Institute of Microbiology, Baku, Republic of \\ Azerbaijan \\ L.X. Asgerli \\ Azerbaijan National Academy of Sciences, Institute of Microbiology, Baku, Republic of \\ Azerbaijan \\ E.İ. Allahverdiyev \\ Scientific-Research Institute of Vegetable of Ministry of Agriculture, Baku, Republic of \\ Azerbaijan \\ C.F. Gasımov \\ Research Institute of Crop Husbandry of Ministry of Agriculture, Baku, Republic of \\ Azerbaijan \\ ${ }^{\star}$ Corresponding author. E-mail: article_1@mail.ru

\begin{abstract}
The purpose of the presented work was dedicated to assess the spread of fungal diseases and the species composition of its creators on the plants used for food purposes in the agraraian sector of Azerbaijan. In the research conducted for this purpose, we studied mycobiota of 20 sorts belonging to the 10 species of plants and it was indicated that in the formation of mycobiota of those plants, there was involvement of 57 species of fungi and fungi -like organisms. It was determined that the frequency of occurrence of registered fungi, as well as the prevalence of diseases caused by fungi depending on the plants, are characterized by the different quantitative indicators. Thus, the total frequency of occurrence fungi varies between $0.02-21.2 \%$. Phytosanitary status was assessed according to the degree of spread of diseases caused by fungi. It became clear that the situation today is potentially dangerous. This is also made as a necessary task to develop serious prophylactic measures.
\end{abstract}

Keywords: Agrarian sector, Degree of spread, Disease, fungi, Food purpose plants

\section{INTRODUCTION}

Providing people with food products in modern times is one of the primary tasks of the economic policy of any country. This issue has gained some relevance on the background of increasing globalization of the problems of our world. The reason for this is that since the second half of the twentieth-century humanity has begun to face situations like energy, food items, as well as the shortage of raw materials for various industries. As a result of this, first of all, should be notes continuous increase of world population within a stable territory, and not always the application of effective approaches and methods during the use of resources. It should be noted that according to the calculation of UN currently millions of people around the world real feels shortages of food and prognosticate that the number of the world's population in 2050 to reach 9.7 billion (John Cleland, 2013, ) which allows us to say that this problem is going to cover an increasing number of people. Now everyone is already thinking about it. The solution to these problem naturally is one of the most priority research areas of biology and agrarian sciences(James et al., 2017). The research conducted in this direction, it has been a long time covering two areas: creating new resources and improving the efficiency of using existing resources (Jenny et al., 2016 ).

On the background of tasks encountered during research carried out in this direction is to provide the world population with plant-based agricultural products (vegetables, melons, fruits, etc.)(James et al., 2017. It is no secret that the plant origin foods due to the biological value are an indispensable component of the human diet. Therefore in research, conducted for the solution 
of these tasks were obtained from high-yielding sorts of the plants. At present, obtaining targeted products from them is one of the most serious results achieved in the direction of eliminating food shortages.

In the world, among the reasons for problems as food shortages takes part loss of a certain part of product produced each year. Diseases caused by various organisms, primarily fungi, play a significant role in the loss of production (Doehlemann et al., 2017, Jun Yang et al., 2017). According to calculations, annually a considerable part of the produced products were lost as a result of pathologies caused by microorganism (Shuping and Elof, 2017). In today's conditions, it is important to take into consideration of this loss. Today around the world extensive research is being conducted to prevent the loss and the solution of this issue is already in a status of a problem that cannot be solved within any particular country.

The importance of the agrarian sector in the economy of the Republic of Azerbaijan and the wide cultivation of agricultural crops (Siemen van Berkum, 2017) allow us noting that the mentioned issues are not unfamiliar to our country. The variety of nature, richness, and diversity of natural soil-climatic conditions have contributed to the spread of several disease-causing fungi in Azerbaijan. It is worth noting that the annual loss of products as a result of diseases is also being observed in Azerbaijan and for that reason in Azerbaijan also conducted research to prevent this(Bakhshaliyeva et al., 2019). Based on the carried results it should be noted that for the solution of this problem there is no enough research material and the problem is still open for research.

Taking this into consideration, the aim of the present work was to identify the species composition of fungi that cause disease on the various agricultural plants used for food purposes cultivated in Azerbaijan and assessment of the phytosanitary status of the prevalence rates of pathologies caused by them.

\section{MATERIALS AND METHODS}

The study was conducted on agrosenosis in large geomorphic units of Azerbaijan, such as the Great Caucasus, Talysh Mountains, and the Kur-Araz lowland. Samples were collected from plants cutivated in the field condition such as tomato (Solanum lycopersicum L.), potatoes(Solanum tuberosum L.), cucumber(Cucumis sativus L.), cabbage(Brassica oleracea L.), corn(Zea mays L.), peas(Pisum sativum L.), beans(Phaseolus vulgaris L.), pumpkin(Cucurbita pepo L.), onion (Allium cepa L.) and eggplant(Solanum melongena L.). For this purpose from vegetative and generative organs (supposed were fungi) of the above-mentioned plants were collected according to the known methods. In the analysis of collected samples were used modern mycology and phytopathological methods and approaches (Golovin et al., 2002, Handbook of Mycological Methods, 2006). In general, more than 700 samples were collected and analyzed during the course of the study.

For the identification, fungi were obtained from their pure culture using pure culture as a nutritional medium viz. Agarzed malt juice(AMJ), Starch (SA) and Potato (PA) agarized, agarized Czapek and Czapek-Dox. The preparation, sterilization of nutrition mediums and preparation for the inoculation were carried according to known methods. The micro- and macro-signs of fungi were obtained from pure cultures and were identified as the taxonomic affiliation according to the determinants made on their basis(Kirk et al., 2008, Satton et al., 2001). Phytopathogenic fungi, which cannot be taken from the pure culture were determined by determinant prepared on the basis of symptoms of pathology and microscopic sign of the various stages of their development cycle.

The frequency of occurrence of fungi by the total number of samples taken from investigated plants were identified by the formula $P(\%)=(n / N) \times 100$ which here $\mathrm{n}-$ the number of plants of which were find fungi in the taken samples, $\mathrm{N}$ - the total number of taken plant samples. Frequency of occurrence was assessed as follows: fungi occurring more than $15 \%$ are dominant, between $1-10 \%$ - frequently encountered, less than $1 \%$ casual or rare species. The phytosanitary situation was assessed according to the international principles (FAO, 2017) and by the degree of prevalence of the fungal disease. The prevalence rate of the disease was calculated according to the formula $P(\%)=(n / N) \times 100$. $P$ - here is the prevalence rate disease, $\mathrm{n}$ - a disease in the study area, $\mathrm{N}$ - is an indicator of the total number of plants.

\section{RESULTS AND DISCUSSION}

The disease of plants used for food purposes is one of the most important issues, at least because the result of any disease caused by fungi is manifested in the loss of products. Interestingly, loss occurs during the cultivation, storage, processing, and use of plants. The study of fungi is related to the fact that most of the diseases currently observed in plants are caused by fungi.

From the analyses of about 700 (at least 50 samples from each plant) samples taken from cultural plants used for food purposes, it became clear that in the formation of mycobiota of these plants, 57 species of fungi and fungi-like organisms were involved. 8 of the recorded fungi (Peronospora brassicae Gaeumann, P. destructor (Berk.)Fr., Plasmodiophora brassicae Woronin, 
Table 1. Species composition of fungi found in the studied plants in all regions (Great Caucasus, Talysh Mountains, and the Kur-Araz lowland) of Azerbaijan.

\begin{tabular}{|c|c|c|}
\hline S.N. & $\begin{array}{l}\text { The studied } \\
\text { plants }\end{array}$ & Registered fungi \\
\hline 1 & Tomato & $\begin{array}{l}\text { Asc.lycopersici, A.alternata, A.solani, B.cinerea, C. fulvum, F.oxysporum, F.solani, } \\
\text { Ph.infestans, Ph.parazitica, S.lycopersici, V.dahliae, V.lycopersici }\end{array}$ \\
\hline 2 & Potato & $\begin{array}{l}\text { A.solani, F.culmorum, F.oxysporum, F.solani, Phoma exigua, Ph.infestans, } \\
\text { Th.cucumeris }\end{array}$ \\
\hline 3 & Cucumber & $\begin{array}{llcc}\text { Asc.cucumeris, } & \text { A.alternata, } & \text { F.oxysporum, } & \text { E.cichoracearum Dc. } \\
\text { cucurbitacearum, C.cucumerinu, P.debarianum, S.cucurbitacearum, V.dahliae } & f .\end{array}$ \\
\hline 4 & Cabbage & $\begin{array}{l}\text { A.alternata, A.solani, F.oxysporum, P.brassicae, Ph.lingam, P.brassicae, Rhizoctonia } \\
\text { solani }\end{array}$ \\
\hline 5 & Corn & $\begin{array}{lccc}\text { A.alternata, } & \text { B.cinerea, } \quad \text { F.oxysporum, } & \text { F.verticillioides, } & \text { G.zeae, } \\
\text { G.graminicola, } & \text { H.maydis, H.turcicum, } & \text { P.sorghi, } & \text { Scl.libertiana, } \\
\text { S.sclerotiorum, S.maydis, S.reilianum, U.zeae } & & \end{array}$ \\
\hline 6 & Pea & $\begin{array}{l}\text { Asc.pinodes, Asc.pisi, A.alternata, E.communis f. pisi, F.avenaceum, F.culmorum, } \\
\text { F.gibbosum, F.heterosporium, F.oxysporum, F.solani, F.semitectum, F.verticillioides, } \\
\text { S.pisi, U.pisi }\end{array}$ \\
\hline 7 & Beans & $\begin{array}{l}\text { Asc.phaseolorum, A.alternata, F.oxysporum, F.solani, } \\
\text { F.verticillioides, S.sclerotiorum, U.appendiculatus }\end{array}$ \\
\hline 8 & Pumpkin & $\begin{array}{l}\text { Asc.cucumeris, A.alternata, B.cinerea, F.gibbosum, F.oxysporum, F.solani, } \\
\text { S.sclerotiorum, St.ilicis, T.roseum, V.dahliae }\end{array}$ \\
\hline $\begin{array}{l}9 \\
10\end{array}$ & $\begin{array}{l}\text { Onion } \\
\text { Eggplant }\end{array}$ & $\begin{array}{l}\text { A.alternata, B.cinerea, F.oxysporium, P.destructor, P.allil, P.porri, U.allii, V.dahliae } \\
\begin{array}{lll}\text { A.alternata, A.solani, B.cinerea, C.lagenarium, C.melongenae, F.oxysporum, } \\
\text { F.gibbosum, F.verticillioides, Ph.melangenae, S. melongenae, V.dahliae }\end{array}\end{array}$ \\
\hline
\end{tabular}

Table 2. Characteristics of fungi by the frequency of occurrence on the separate studied plants.

\begin{tabular}{|c|c|c|c|}
\hline Plants & Dominant species & Often encountered species & Random or rare species \\
\hline Tomato & $\begin{array}{l}\text { Asc.lycopersici, A.solani } \\
\text { V.lycopersici }\end{array}$ & $\begin{array}{l}\text { B.cinerea, } \\
\text { Ph.infestans, V.dahliae }\end{array}$ & $\begin{array}{ll}\text { A.alternata, } & \text { F.oxysporum, } \\
\text { C.fulvum, } & \text { Ph.parazitica, } \\
\text { S.lycopersici } & \end{array}$ \\
\hline Potato & $\begin{array}{l}\text { Phoma exigua, } \\
\text { Ph.infestans, }\end{array}$ & A.solani, F.oxysporum & Th.cucumeris F.culmorum F.solani \\
\hline Cucumber & Asc.cucumeris, V.dahliae & $\begin{array}{l}\text { A.alternata, F.oxysporum, } \\
\text { E.cichoracearum Dc. } f . \\
\text { Cucurbitacearum }\end{array}$ & $\begin{array}{l}\text { P.debarianum, C.cucumerinum, } \\
\text { S.cucurbitacearum }\end{array}$ \\
\hline Cabbage & A.solani, P.brassicae & $\begin{array}{l}\text { A.alternata,F.oxysporum } \\
\text { Ph.lingam }\end{array}$ & Pl.brassicae, Rh.solani \\
\hline Corn & $\begin{array}{ll}\text { G.zeae, } & \text { H.maydis, } \\
\text { S.sclerotiorum, } & \text { S.maydis }\end{array}$ & $\begin{array}{lr}\text { A.alternata, } & \text { F.oxysporum, } \\
\text { G.graminicola } & \text { H.turcicum, } \\
\text { Scl.libertiana } & \end{array}$ & $\begin{array}{l}\text { B.cinerea, F.verticillioides, } \\
\text { P.sorghi, } \\
\text { S.reilianum, U.zeae }\end{array}$ \\
\hline Pea & Asc.pisi, U.pisi & $\begin{array}{l}\text { A.alternata, } \quad \text { F.avenaceum, } \\
\text { F.culmorum, F.gibbosum, } \\
\text { F.oxysporum, F.solani, }\end{array}$ & $\begin{array}{l}\text { Asc.pinodes, E.communis f. pisi, } \\
\text { F.heterosporium, F.semitectum, } \\
\text { F.verticillioides S.pisi, }\end{array}$ \\
\hline Beans & $\begin{array}{l}\text { Asc.phaseolorum, } \\
\text { U.appendiculatus }\end{array}$ & $\begin{array}{l}\text { A.alternata, F.oxysporum, } \\
\text { F.solani }\end{array}$ & $\begin{array}{l}\text { F.heterosporium, F.verticillioides, } \\
\text { S.sclerotiorum }\end{array}$ \\
\hline Pumpkin & Asc.cucumeris & $\begin{array}{l}\text { A.alternata, } \quad \text { F.gibbosum, } \\
\text { F.oxysporum, F.solani }\end{array}$ & $\begin{array}{ll}\text { B.cinerea, } & \text { S.sclerotiorum, } \\
\text { St.ilicis, T.roseum, V.dahliae }\end{array}$ \\
\hline Onion & $\begin{array}{l}\text { P.allil, P.porri, } \\
\text { V.dahliae }\end{array}$ & A.alternata, F.oxysporium & B.cinerea P.destructor \\
\hline Eggplant & $\begin{array}{l}\text { C.lagenarium } \\
\text { F.oxysporum, } \\
\text { Ph.melangenae }\end{array}$ & $\begin{array}{l}\text { A.alternata, } \\
\text { B.cinerea, } \\
\text { F.gibbosum }\end{array}$ & $\begin{array}{l}\text { F.verticillioides, } \\
\text { S.melongenae, V.dahliae }\end{array}$ \\
\hline
\end{tabular}

Pythium debarianum R. Hesse, Phytophtora infestans (Mont.) De Bary., Ph.melangenae, Ph. parazitica Dastur, Ph. phaseoli Thaxter) belonged to the kingdom of Chromista, and 48 to the kingdom of Mycota. 8 species of fungi(Erysiphe communis f. pisi (H.A. Dietr.) Jacz., E.cichoracearum Dc. f. cucurbitacearum Poteb., E.pisi DC., Gibberella zeae (Schwein.)Petch., Helminthosporium maydis Y. Nisik. \& C. Miyake,
H.turcicum Pass. Sclerotina libertiana Fuskel. və Sclerotinia sclerotiorum (Lib.) de Bary.) belonged to the kingdom of Mycota that belongs to the telemorphs from the division of Ascomycota, 31 species(Ascochyta cucumeris Faurtr. et Roum, Asc. lycopersici Brun., Asc.phaseolorum Sacc., Asc.pisi Lib. Asc.pinodes L.K. Jones., Alternaria alternata (Fr.) Keissl., A.solani Sorauer, Botrytis cinerea Pers.:Fr., Cladosporium cucumerinum Ell. 
et Arth, C.fulvum Cooke, Colletotrichum lagenarium (Pass.) Ell. et Halst, C.melongenae Lobik., C.pisi Pat., Fusarium oxysporum Schlecht, F. solani (Mart.) Appel et Wr., F.gibbosum App. et Wr., F.avenaceum (Fr.) Sacc., F.culmorum (Sm.) Sacc., F.heterosporium Nees., F. semitectum Berk. et Rav.,F.verticillioides (Sacc.) Nirenberg, Glomerella graminicola D.J. Politis., Phoma exigua Desm., Phoma lingam (Tode) Desm., Septoria cucurbitacearum Sacc., S.lycopersici Speg., S. maydis Schulzer \& Sacc, , S. melongenae Lobik, S.pisi West., Stemphylium ilicis Tenqwall, Trichothecium roseum Link, Vertisillium dahliae Kleb., V.lycopersici Pitchard et Porte) belonged to the anamorphs from the Division of Ascomycota, 10 species(Puccinia allil (DC.) Rudolphi, Puccinia sorghi Schw., P.porri (Sow.) Wint., Rhizoctonia solani J.G. Kuehn, Sorosporium reilianum (Kuehn) McAlp., Thanatephorus cucumeris (A.B. Frank) Donk., Uromyces appendiculatus F.Strauss, U.pisi (Pers.) de Bary, Ustilaqo allii McAlp, U.zeae (Link) Unger ) belonged to the Division of Basidiomycota.

All of the recorded fungi have been found in Azerbaijan in previous studies also and were determined that all of them cause certain diseases in one or another plant (Bakhshaliyeva et al., 2019). From this aspect, only fungi Fusarium verticillioides and Sorosporium reilianum are an exception. The registration of this fungi in the territory of Azerbaijan is for the first time. All of the fungi recorded in the studies are phytopathogenic and the disease caused by them are such as fusariosis, fade, rust, flour dew, decay, septoria, alternariose, ascochitosis, etc. on the host plants have been also confirmed in other conducted studies. The results of all these diseases, those or that degree causes to decrease the productivity of host plants.

It was noted that the distribution of fungi recorded on studies plants was different. Although the number of plants where spreads of some fungi were limited, but to the list of substrates inhabited by some fungi included all of the studied plants. This can also be seen in the list of fungi species involved in the formation of the pathogenic mycobiota of individual plants(Table 1). As seen, while fungi such as Alternata, B.cinerea, F.oxysporum and Verticillium dahliae have a wide range list of host-plants, the fungi species such as Erysiphe communis $f$. pisi, Peronospora brassicae, Plasmodiophora brassicae, Puccinia allil and Sorosporium reilianum have a single host -plant. In general, it was noted that the number of species involved in the formation of the pathogenic mycobiota of the studied plants depending on plants is characterized by variable number. For example, the formation of pathogenic mycobiota of corn involved 14 , tomato
12 and onions 8 species. In the formation of the mycobiota of each 3 plants, there was participation of only A.alternata, B.cinerea, and F.oxysporium. The fungi involved in the formation of the mycobiota of this or that plant had a negative impact on the overall productivity of the plants, and quantitative indicator of the damage to the plant productivity from their effects also varied. As a rule, to determine of their uses, either the frequency of occurrence of that phytopathogenic fungus, or spread degree of the disease caused by them, were responsible. Both of the abovementioned approaches create the same degree of an impression about the decrease of productivity in the plants. Therefore, registered fungi at the next stage of research were also characterized by the frequency of occurrence on both common and individual plants.

These indicators by the practical considerations are more favorable at least for the reason that the fungi cause disease. As a rule, when fungi characterized by the frequency of occurrence, they divide into 3 groups (dominant, often encountered, random or rare species). Fungi recorded in the studies have also been characterized according to this system. İ became clear that the total frequency of occurrence of fungi that do not have substrate septicity is higher. In general, the distribution and frequency of occurrence of fungi in these groups are as follows: Dominant species. This group by the frequency of occurrence included fungi such as A.alternata, B.cinerea, F.oxysporium, and V.dahliae. These fungi were characterized by a higher(15.5-21.1\%) frequency of occurrence on the mycobiota of all studied plants. Therefore, they can be considered as the dominant species of pathogenic mycobiota of the studied forage plants of Azerbaijan.

According to the frequency of occurrence, the fungi such as A.solani, F.solani, F.gibbosum, F.verticillioides, Phytophtora infestans, and $S$. sclerotiorum can be attributed to the second group which would be better named it as often encountered. The frequency of occurrence of included in those groups varied between 1.4$8.4 \%$. These fungi mainly consisted of those have relatively low substrate specificity.

The third group can be attributed to random species of which 47 species of registered fungi are consistent with these characteristics. The frequency of occurrence of these varied between $0.02-0.70 \%$.

It would be appropriate to clarify a point regarding the grouping of recorded fungi. The noted division carried the conditional character. Thus, nearly all of the registered fungi characterized only one host -plant belonged to the third group, in other words, are characterized as random species. Among those, fungi species also taking part, considered dangerous disease creator for concrete plants. 
Therefore, it is possible to more accurately estimate the extent of loss occurred due to disease if specific plant mycobiota assessed on an individual approach. For example, the frequency of occurrence of $A$. solani on the tomato plant makes up $7.0 \%$, which one of the dangerous disease creators of tomato, however, the frequency of occurrence of these fungi in the course of research was contained as $2.3 \%$. A similar comparison can be shown on other plants too. In short, even today, the principle of individual approach to the particular plant remains its effect. Taking this into consideration, as a result of the research, fungi involved in the formation of mycobiota of each studied nutritional plants were assessed according to the degree of danger. The main indicator for this process was taken as the frequency of occurrence of fungi spread on the specific plant species and sorts. The occurrence of species of fungi for individual plants are given in Table 2.

The species of fungi for individual plants according to the general conclusion are classified as random species. According to the aforementioned "Individual approach to a particular plant", the data in Table 2 can be considered useful information in the development of preventive measures to eliminate the cases which may cause decrease in the productivity of nutrients grown in Azerbaijan in the future.

It should be noted that fungi causing various pathological changes in plants every year, reduce their productivity, and currently, the amount of the loss is characterized by millions of tons. In the case of ephitoty of this or that disease, the loss of product can reach even up to $100 \%$. From the present research, it became clear that Azerbaijan is also feeling the effect of fungi to the productivity of many plants grown for nutritional purposes and the loss of product each year from their impact becomes inevitable. True that today it is impossible to say the exact figure about the loss of plants, even in the case of a concrete plant. But, we can say with certainty that the problem should be taken into account in the conditions of Azerbaijan too. Although during the period of research (2015-2019), besides of some local characters did not meet wide ephitoty of any disease However, the interest of evaluating of the phytosanitary situation in the country for the example of the studied plant is not in the doubt. For this, assessment scale has been currently used for this purpose, and according to the document if prevalence degree of the disease contains $20-30 \%$, it shows that the phytosanitary situation is potentially dangerous. (Toropova and Kirichenko, 2012 ). From the above -mentions, it became clear that the frequency of occurrence of fungi neither individually nor at generally does not reach to this number. It should be noted that at present, the phytosanitary situation in Azerbaijan is generally on the potentially dangerous level. Nevertheless, we should not ignore the likelihood of increasing the danger from potential to reality. Therefore, the development of preventive measures is one of the main tasks of researches to be carried in this area of Azerbaijan.

\section{Conclusion}

It was concluded that agricultural plants used for the nutritional purpose in Azerbaijan by the species composition of mycobiota and frequency of occurrence on the substrates was in the formation of mycobiota of 10 plant species and their various sorts(about 20) that involved 57 species of fungi and fungal-like organisms. All of them caused various diseases in plants and the frequency of occurrence of their creators in plants varied between $0.02-21.2 \%$. Assessment of the phytosanitary situation of the studied plants showed that today the situation is potentially dangerous. It shows the the necessity to develop preventive treatment measures.

\section{REFERENCES}

1. Bakhshaliyeva K. F., Cabrayılzadə S.M., İslamova Z.B., Namazov N.R. and Hasanova A.R. (2019). The General Characteristic of Anamorphic Fungi Spread In Azerbaijan. International Journal of Recent Technology and Engineering (IJRTE), 8,3:2208-2210. DOI:10.35940/ijrte.C4591.098319

2. Doehlemann G., Ökmen B., Zhu W., Sharon A. (2017). Plant Pathogenic Fungi. Microbiol Spectr., 5 (1). doi: 10.1128/microbiolspec.FUNK-0023-2016.

3. FAO (2017). Preparing a national phytosanitary capacity development strategy A phytosanitary capacity development training tool for NPPO. Food and Agriculture Organization of the United Nations Rome: FAO, 40. http://www.fao.org/3/i7766en/I7766EN.pdf

4. Golovin P.N., Arseneva M.V., Tropova A.T. and Shestiperova Z.I. (2002). Workshop on general phytopathology. SPb . Lan publishing house, 288.

5. Handbook of Mycological Methods (2006). http:/l www.fao.org/fileadmin/user_upload/ agns/pdf/coffee/ Annex-F.2.pdf

6. James W. Jones, John M. Antle, Bruno Basso, Kenneth J. Boote and Richard T. Conant (2017). Brief history of agricultural systems modeling. Agric Syst. Jul; 155: 240-254. doi: 10.1016/ j.agsy.2016.05.014

7. Jenny (Jingxin) Tian, Brian C. Bryksa and Rickey Y. Yada (2016) Feeding the world into the future - food and nutrition security: the role of food science and technology, Frontiers in Life Science, 9:3, 155-166, DOI: $10.1080 / 21553769.2016 .1174958$

8. John Cleland (2013). World Population Growth; Past, Present and Future. Environmental and Resource Economics 55(4):543-554. DOI: $10.1007 /$ s10640013-9675-6

9. Jun Yang, Tom Hsiang, Vijai Bhadauria, Xiao-Lin Chen and Guotian Li. (2017). Plant Fungal Pathogenesis. Biomed Res Int., 2017: 9724283. Published online 2017 Jan 17. doi: 10.1155/2017/9724283

10.Kirk P. M., Cannon P. F., Minter D. W. and Stalpers 
Muradov, P.Z. et al. / J. Appl. \& Nat. Sci. 11(4): 785 - 790 (2019)

J.A. (2008). Dictionary of the fungi, 10th edn. CABI publishing. Wallingford (UK), 600.

11.Satton D., Fothergill A. and Rinaldi M. (2001). Determinant of pathogenic and conditionally pathogenic fungi. M: World, 486.

12.Shuping D.S.S. and Elof J.N. (2017). The use of plants to protect plants and food against fungal pathogens: a review. Afr J Tradit Complement Altern Med.; 14(4): 120-127. Published online 2017 Jun
5. doi: 10.21010/ajtcam.v14i4.14

13.Siemen van Berkum (2017). Market and competitiveness analysis of the Azerbaijan agricultural sector: an overview (Wageningen Economic Research), 33

14.Toropova E.Yu. and Kirichenko A.A. (2012).

Phytosanitary environmental monitoring: a method of pointing to a lab. classes and control work Novosibirsk: Publishing House of the NSAU, 41 